\title{
Стил и пародија у Пантологијама Станислава Винавера
}

\author{
Ђорђе Н. Кебара* \\ Универзитет у Крагујевцу, Филолошко-уметнички факултет
}

\begin{abstract}
Кључне речи:
пародија, стил

антологија

пеленгирика

збирка пародија

аспект писца
\end{abstract}

\begin{abstract}
Апстракт
Предмет овог рада је књижевно-стилистичка анализа збирке пародија Пантологија С. Винавера. Метод утврђивања особености збирке и стилистичких чињеница биће дедуктивног карактера, односно, у погледу закључивања од општег ка посебном. Циљ рада је постављање збирке, на књижевно-историјском плану, у контекст пародијског писања унутар српске књижевности. Поред тога, значајно је одређивање стилематичности ауторовог текста или метатекста, као и аспект ауторових фигура у тексту - пародије, ироније, алузије и сл. Винаверово писање у пародичном маниру поставићемо као аспект писца или контекстуализацију света аутора текста, критику моде у стваралаштву, односно, његову хумористичку визију изокренутог света. Винаверову пародију представили смо посредством петоделне поделе, коју сачињавају: пародија епохе, пародија писца, пародија жанра, пародија манира и пародија атмосфере. Очекивани резултат рада односи се на схематично разврстану типологију смеха и комедије С. Винавера, а у погледу песничке хумористичне збирке Пантологија. (примљено: 22. јуна 2021; прихваћено: 30. октобра 2021)
\end{abstract}




\section{1. Типологија комедије Станислава Винавера}

Писање збирке пародија односи се на периодично издавање ${ }^{1}$ Пантологије ${ }^{2}$ и њених допуњених издања: Пантологија новије српске пеленгирике (1922); Нова пантологија пеленгирике (1922); Најновија пантологија српске и југословенске пеленгирике (1938). Пародичним текстовима придружује се Алајбегова слама ${ }^{3}$, у којој се пародирају текстови из народне књижевности, али и Чардак ни на небу ни на земљи (1938), у којем су пародирани књижевно-теоријски есеји и трактати. Као корпус наше анализе, употребљаваћемо појединачну верзију збирке Пантологија српске и југословенске пеленгирике у виду послератног избора ${ }^{4}$ текстова које је Ј. Христић (1933-2002) приредио за Нолитово издање 1966. године, али у компарацији са појединачним Нолитовим издањем, користићемо и пародије објављене у склопу вишетомних дела Станислава Винавера: Пантологије, Алајбегова слама, у оквиру сабраних Дела Станислава Винавера у заједничком издању Службеног гласника и Завода за уџбенике из 2012. године, које је приредио Гојко Тешић (1951-).

Пантологија новије српске пеленгирике С. Винавера (1891-1955) скуп је текстова написаних у пародичном маниру који су усмерени претежно на значајне писце српске књижевности романтизма и модерне или, како Поповић (1863-1944) истиче, писце „новије српске лирике“ (1994: 11). Критичар наглашава како српска лирика у поменутом периоду „показује изванредно правилан, управо типичан развој једне оригиналне лирске цвасти“ (Поповић, 1994: 11). С тим у вези, наводе се разлози за начињени одабир:

Под новијом српском лириком - „модерном“, као што је стајало у позиву којим је „Матица Хрватска“ уредника почаствовала - уредник је разумео нашу лирику од Бранка Радичевића на овамо. Тај период наше лирике чини једну заокругљену, органску целину, коју не би било упутно цепати на делове. (Поповић, 1994: 11)

Текстови Пантологије фреквентно припадају поезији, али су уврштени и прозни и есејистички књижевни облици. Функционални стил, доминантан у пародичном маниру српског писца, књижевно-уметничког је карактера, изра-

1 Засебни делови, касније интегралне збирке, излазили су превасходно у листовима Штампа и Пијемонт 1911-1913.

2 Сељачки Мирковић наводи могућу семантику насловних одредница „пантологија“ и „пеленгирика“, али и одређене стилске преображаје: „[...] док се израз пантологија може доста једнозначно протумачити као пародијска антологија, реч „пеленгирика“, која несумњиво алудира на ^ирику, својим првим сегментом буди асоцијацију на реч „пелен“, која означава биљку горког укуса, али фигуративно и горчину, јад, чемер, што би могло бити алузија на, горко, јадно стање наше тадашње лирике [...] корен те речи могао би бити и пелѐнгйр, „мали стуб о који је пре батињања везан какав злочинац да га сви виде“ [...] Могуће тумачење пружа и реч „пеленгири“, то јест „пелѐнгаће“, широке мушке гаће, чакшире од грубог сукна до ниже колена“ (2015: 610-611).

3 Постхумно објављена збирка 1969. године. Објављен је само део рукописа Алајбегове сламе.

4 Христићево прирећено издање видимо као сублимацију претходних верзија Винаверових Пантолгија, избор који представља закључни поглед на претходне варијанте. 
жен посредством естетског субјекатско-објекатског односа (уп. Тошовић, 2002: 244), али есејистички текстови са полемичким тоном улазе у интерсекцију и са публицистичким стилом. На плану поезије, пародија се односи на хетерогеност жанрова, пародирају се фолклорне лирске, епске и лирско-епске песме, оде, елегије, романсе ${ }^{5}$ (уп. Винавер, 2002: 14-15). Пародија је усмерена на друге песнике српске књижевности модерне, али и романтизма и фолклоризма - народно песништво, као и авангардне тековине, чији је и Винавер био поборник.

Према Хамовићу, „Винавер је пародијским испитивањем и коментаром нашој књижевној уметности прибавио могућност да се осети свеснијом, а његове пародије нуде обухватно превредновање српске књижевности“ (2015: 604). Пре самог песништва српског, предмет Винаверове пародије је књига Антологија новије српске лирике (1911) водећег књижевног критичара Б. Поповића, односно, конкретан предмет критике огледа се у појави књижевног канона у погледу утилитарне и пригодне поезије, приликом чега, као главне утемиљиваче, Винавер види у критичарима: Б. Поповићу, П. Поповићу (1868-1939), Ј. Скерлићу (1877-1914) и Б. Лазаревићу (1883-1963), као и писцима главним протагонистима таласа академизма у српској поезији: Ј. Дучићу (18746-1943), М. Ракићу (1876-1938), М. Бојићу (1892-1917).

Основну вредност збирке пародија С. Винавера можемо пратити кроз ставове, истакнуте у есеју Језичне могућности (1922), где се истиче потреба за пробојем хумора у муклу и пркосну десетерачку традицију српског песништва (Хамовић, 2015: 585). Критика песништва које прати десетерачку традицију, критика је неиновативности песничког језика „песник не наставља своју мисију него мисију народне песме“ (Матицки, 1990: 2010). У Винаверовом стваралаштву уочљива је „поетика неконвенционалности, неретко и антитрадицоналистичког типа“ (Брајовић, 2015: 116). У поменутом есеју, ипак, наслућује се како Винаверови напади нису усмерени на са́му десетерачку традицију, што би био врхунац логичког апсурда и културног самопорицања7.

5 Романса је песма кастиљанског порекла, произашла је из народне поезије и углавном се рецитује некој госпи. Српски песници модерне повремено су подражавали шпанске романсе и тему витешког удварања. Такви примери могу бити песме о ликовима Дон Фернанду и Дона Бјанки. Песму са оваквом тематиком у свом опусу има В. Илић (1862-1894), али и М. Митровић (1867-1907), а пародирана песма из Пантологије „Дон Фернандо“, управо је амалгам песама два аутора, номинално приписана Митровићу (уп. Винавер, 2002: 14-15).

6 Постоје многи спорови о години рођења Ј. Дучића: у каталогу Матице српске поводом електронске изложбе о Ј. Дучићу наводи се у наслову „1871-1943“ (Станојевић/Николић 2021: 4), али унутар књиге стоји примерак крштенице из песникове оставштине у којој пише: „Оригинална црквена документа нису сачувана, али је у Дучићевој оставштини сачувано „Увјерење“ које - с потписом пароха требињског проте Владимира Јовановића, а датирано с 8. априлом 1938 - „вриједи као крштеница“: ту се тврди да је песник „рођен у Подгливљу код Требиња дана 15. фебруара 1874. год“ (Станојевић/Николић, 2021: 8).

7 Већ почетном, уводном реченицом, Винавер наводи вајлдовску парадоксалност о истинитости уметности и лажи живих подражаваоца уметности: „Уметност створи Вертера, Хамлета, Корину, Аталу; а живи људи стану подражавати Вертеру, Атали“ (Винавер, 1963: 143). Даље, у тексту, истиче разлоге немогућности живог језика да настави десетерачку традицију: „Језик који данас имамо није више у досегу народног стварања. Оно се упутило другим правцем. Језик је постигао извесну уобличену и живу ограниченост [...] сада он има да уобличи и уобличава човека који к њему иде, бившег ствараоца. Не само да човек јуначких 
Винаверова Пантологија једина је збирка пародичне поезије у српској књижевности и као таква представља осамљену појаву, али на плану светских токова проналази се пандан у збиркама М. Пруста, М. Бирбома, С. Конолија, П. Ребуа и Ш. Милера (Христић, 1966: 199). Пре него утврдимо иманентне особености пародије С. Винавера, нужно је одредити природу пародије и њену функцију у књижевно-стваралачком поступку. Пародија, у дословном преводу са грчког језика, значи „супротна песма“ или песма испевана поводом неке друге песме, што је најопштија дефиниција и погодан почетак анализе пародирања у Пантологији. Песничка пародија, дакле, комична је и подругљива имитација друге песме (Bandić, 1992: 570). Значајно је истакнути израз „имитација“ зато што је имитација основни предуслов хумористичког говора - мимезис ${ }^{8}$ и мимикрија9. Према Лешићу, „Пародија је субверзивна имитација стила неког туђег књижевног дјела или цијеле једне књижевне школе с циљем да се истакну слабе тачке тог стила“ (2010: 300). Истичемо, дакле, да је хумористички стил говора аутора основни предуслов постанка Пантологије, а хуморизам ${ }^{10}$ какав имамо у виду, када је реч о Винаверу, вербалног је карактера.

Одредити Винаверову Пантологију као хумористичну ${ }^{11}$, у погледу смеха ${ }^{12}$, може бити тачно, али не и најпрецизније. Како бисмо размотрили значајне аспекте смешног у Винаверовој збирци пародија, потребно је поставити неку врсту типологије смеха ${ }^{13}$. Смех или смешно у књижевном или уметничком, представљачком поступку, може имати сопствену класификацију, али она никада није строго утврђена. Проп (1895-1970) у Проблемима комике и смеха (1984) наводи разматрање историчара филма Р. Јурњева:

Смех може бити радостан и тужан, доброћудан и гневан, паметан и глуп, охол и простодушан, снисходљив и понизан, презиран и уплашен, увредљив и утешан, дрзак и плашљив, пријатељски и непријатељски,

песама више не ствара језик (он га је створио у првом стадијуму) већ сада тај језик, који је отишао даље, неодољиво дела - да му се не може нико отети“ (Винавер, 1963: 145).

8 Подражавање и домишљање приче.

9 Израз који се изворно користи за описивање сличности међу животињама. Мимикрија означава сталну или привремену сличност. У овом контексту, посматрамо сличност на плану текста.

10 Хумор посматрамо као стилогену вредност дела. Разлоге за такво становиште проналазимо у функцији комике у Винаверовој збирци као стилског поступка онеобичавања и наговештај необичности текста. Аналогија се може тражити стилској употреби експресивних израза, екскламације и интерпункције.

11 Игор Перишић, у студији Увод у теорије смеха, а у контексту саодноса хумора и комике, истиче: „комика је само једна маска хумора, маска коју он ставља да би могао изаћи пред публику. Из овога следи да је хумор виши поетски облик смешног [...]“ (Perišić, 2012: 34)

12 Према томе, смешно у Винаверовој Пантологији, изводимо из једног вишег нивоа препознавања смешног у оквиру разумевања смеха на когнитивној равни, а у контексту поетског текста. Перишић наводи: „многобројни проучаваоци су утврдили да као и у случају смеха и комедије, не да не мора постојати, већ и да веза између хумора и ефекта смеха није од кључног значаја. Често хумор производи смех, али је некад резултат и само осмех.“ (2012: 30)

13 Хумор С. Винавера изражено је референцијалан, стога, ефекти исмевања унутар његове комике, не припадају толико грубој вулгарној комици, колико рачунају на ефекат препознавања текста, према Перишићу, односи се на когнитивну промену - сазнајни приступ (2012: 31). 
ироничан и простодушан, саркастичан и наиван, умиљат и груб, значајан и безразложан, тријумфалан и извињавајући, непристојан и збуњен. Могли бисмо још набрајати: весео, тужан, раздражљив, хистеричан, поспрдан, физиолошки, животињски. Смех може да буде чак и сетан! (Prop, 1984: 27)

Проп надопуњава наведену поделу тако што придодаје облик „подсмешљивог смеха“ (Prop, 1984: 28). У питању је смех који је ругалачког карактера. Проповом избору прикључићемо и врсту критичког смеха. Поред тога, подсмешљиви ${ }^{14}$ смех назваћемо „критизерским“, чиме добијамо опозицију критизерски смех/критички смех ${ }^{15}$. Пародија, супротно бурлескном исмевању стварности - исмевању ради гега или вица, односи се на критику књижевног и културног живота. Д. Вукићевић истиче:

Пародију смо издвојили као битну цитатну релацију у реалистичким текстовима јер се управо њоме удара на ауторитет текста. Ипак, не можемо а да не приметимо њен унутрашњи парадокс - она није само полемички дијалог са другим текстом, она је и нека врста тродуплог текста, текста са „дуплим дном“ који истовремено ревитализује и „оспорава“ туђи текст и ствара нови. (Вукићевић, 2018: 58)

Најчешће се пародирају језик писца или дела, карактеристике књижевног дела, књижевне врсте, особености жанра, стил епохе. Карактеристичне особине, посебно се наглашавају, хиперболишу се и, карикирањем, имитирају, док не постану смешне. Винавер, дакле, конструише пародичан текст у жанровском облику свог прототекста. С тим у вези, Перишић каже „када писац пише у обрасцу жанра а да га не мења, он га пастишира“ (Perišić, 2006: 66). У наставку текста додаје да је пастиш увек подврста пародије (Perišić, 2006: 66). Позиција у којој се Винаверова збирка остварује као пародија јесте место на ком се познати текст (преузимање форме, жанра, атмосфере познатог прототекста - пастиширање књижевности) ${ }^{16}$ трансформише у преобликовани „текст о тексту“ (исти формални

14 Ж. Женет (1930-2018) смех који именује као „risible“, у класификацији смеха, претпоставља као „подсмех, а не чисти смех“ (Perišić, 2012: 27). Перишић сматра да „не постоји адекватан превод који би се састојао од једне речи (подсмешљиво је пре епитет него име предмета)“. (Perišić, 2012: 27) С друге стране, именовање предмета не може се правилно изводити адвербијалним обликом, а „подсмех“ или колоквијални вулгаризам „поспрда“ сасвим су задовољавајући номинални облици.

15 Разлика између критике и критизерства је место на коме ћемо градити оправданост Винаверевог дела. Критизерство, као основну функцију, има ругалачки карактер или неаргументовано и неконструктивно критиковање појединца, друштва и појава. Критика представља опозитну страну критизерству и ваљани осврт на добре и лоше карактеристике појединца, друштва и појава. Пародија Винаверове Пантологије може се посматрати као широк осврт на модерно српско песништво, али и као његова критика.

16 Блискост пародије и пастиша Перишић објашњава на следећи начин: „Ова два феномена често су помешана, на истом месту се може говорити и о једном и о другом. Пастиш није неутралан као што ни пародија није увек исмевајућа. Пародија је у постмодернистичкој књижевности најпре друго име за интертекстуалност. Жанр може бити пастиширан, а да значење таквог текста буде пародијско“ (Perišić, 2006: 65). 
оквири, а другачија или супротна семантичка вредност - пародични метатекст). По питању стилистичких особености збирке, пародију посматрамо као појам на међи на којој се разграничавају жанр, род и стилска фигура ${ }^{17}$. Пародија, функцијом комичног, може се класификовати као поджанровска јединица комедије (књижевни род) али, иманентним антитетичним ${ }^{18}$ особеностима, може се пратити и њен стилогени ${ }^{19}$ развој у делу - уметнички ефекат језичке јединице (в. Ковачевић, 2015: 7).

Пародија, дакле, иако није фигура, у нормативном погледу, поседује нешто што ћемо назвати „стилогени потенцијал“. Она не може постати стилистички довршена фигура из разлога што недостаје стилематични аспект или језички онеобичен облик, за који мора да тражи испомоћ у другим фигурама (поређење, метафора, парадокс). Стога, пародија не може бити уврштена како у тропе или фигуре речи тако ни у фигуре мисли, али функција, коју аутор текста употребљава у стилогеном потенцијалу, проналази други формативни простор. Пародију, у том погледу, тумачимо по узору на Лешићеву класификацију као аспект света и аспект текста (2010: 282), што происходи и у самом аспекту писца - његовог погледа на свет. Пародија, можемо рећи, ако се не односи ни на фигуре речи, ни на фигуре мисли, може се односити на „фигуре погледа“. Иако је констатација смела, у питању је условно терминолошко одређење, које посебан фокус усмерава на ауторов поглед ${ }^{20}$ (уп. Lešić, 2010: 282) на свет што је, сматрамо, главни узрок и полазиште пародирања или критичког смеха.

Питање уметничке аспектулизације света/предмета најчешће се повезује са визуелним уметностима (сликарство, вајарство, архитектура, филм), али визуелизација је значајна и за књижевност. Без обзира на то што се уметнички поступак у књижевности заснива на речима, imago је значајан аспект књижевног дела. Имагинативни процес свести реципијента, приликом читања књижевног дела, процес је приликом конституисања менталних слика, на тај начин функционише уобразиља - креира се слика, а слик или рима, такође, миметични су вербализовани пренос слике на документ. Лешић у својој Теорији књижевности питање „виђења“ уочава не само релевантним за структурисање наратива него и као књижевно-уметничко виђење:

Питања ко види? Како види? И из којег угла? Која преокупирају наратологе могу се поставити пред сваким умјетничким дјелом у којем се

17 Стилистички, пародија се посматра као фигура опонашања текста, стила, писца или јунака, а то опонашање је у нескладу са темом. Наводе се три типа пародије: 1) вербални (променом појединих речи тривијализује се дати предмет); 2) комични или ироични (имитирање стила писца); 3) тематски (пародирање теме и форме). У анализи ћемо приказати присуство сва три типа пародије у Винаверовој Пантологији.

18 Појмови и формације које задржавају антитетична својства попут пародије, али више припадају погледу на свет него фигурама, такође, јесу апсурд и гротеска.

19 Стилогеност у тексту посматрамо као стилску вредност дела, насупрот стилематичности - онеобичавање форме.

20 Ауторов поглед присутан у делу његова је теоријско-идеолошка тачка ослонца. Становиште аутора у наратологији се често наводи као point of view (в. Кебара, 2020: 239). 
конституише неки конкретан свијет, тј. свијет састављен од различитих „предмета“ (ствари, појава, људи, збивања). Пошто у уметности никад немамо посла са предметима као таквим, већ увек са предметима представљеним на известан начин, онда је „вид предмета“ (тј. „оно што се види“) увијек одређен оним посебним виђењем које у дјелу доминира.“ Другим ријечима, предмети у умјетности [...] се јављају аспектуализовани [...] (Lešić, 2010: 282)

Према Сељачки Мирковић, зачетак пародијске мисли С. Винавера налази се у његовој раној збирци Мјећа ${ }^{21}$ (1911), а она настаје као утук каснијим пародијама које се односе на Поповићеву антологију (2015: 605). Писци који су се нашли предметом пародије подвучени се, пре свега, као карактеристични примери савремене књижевне ситуације (Б. Радичевић - 1824-1853; J. Ј. Змај - 1833-1904; Ђ. Јакшић - 1832-1878; Л. Костић - 1841-1910; Ј. Дучић; С. Пандуровић - 1883-1960; М. Бојић - 1892-1917). Њихову улогу, као објекта пародије С. Винавера, видимо као подсмешљиви приказ у погледу послушних схоластика J. Скерлића. Винавер пародира поступак и стил старих узора, за које сматра да је потребно превазићи, пародира своје савременике, чију поезију види као моду академизма и миметизам страних узора. Његовој пародији нису измакли ни савременици, миљеници па ни саборци у погледу авангардних поетичких струјања (М. Црњански - 1893-1977; Р. Петровић - 1898-1949). На том месту, такође, уочавамо и моменат аутопародије. Пародију писаца који се налазе на поетичкој равни блиској на којој је и Винавер, Ранчић види као афирмативну пародију (Rančić, 2012: 66). Таква пародија претпоставља врсту критичке наклоњености писца пародије према предмету пародије (другом писцу, песми, стилу, поетици) (уп. Rančić, 2012: 66). У том погледу, интересантан је Винаверов однос према песништву Л. Костића. Винавер је, заправо, аутор монографије о Костићу, а посебна блискост двеју поетика може се тражити у склоностима аутора ка хиперболизацији израза и неологизмима (уп. Rančić, 2012: 73).

Чињеница о широком опсегу предмета пародирања говори нам о посвећеној и раширеној варијантности хумористичког писања. Винавер је, поред хуморизма, писао и озбиљну метафизичку поезију инспирисан песницима француског симболизма 22 . На плану песничке славе, није заузео високу позицију, па је плодотворнији песнички израз пронашао у комици. Винавер има интересантну библиографију комичне литературе. Писао је песничке збирке у пародијском тону (Мјећа; Пантологија; Чардак); пародирао је поетске, прозне, есејистичке и публицистичке текстове; уређивао је књиге и издања сличног карактера (у

21 У контексту ове збирке Ј. Вјежбицки сматра да Винавер на плану песништва није постигао оно што је постигао Дучић, али његова теоријска схватања о симболизму испред су Дучићевих и осталих модерниста. Мјећа представља духовиту лектиру француских симболиста и српских савремених песника (Хамовић, 2015: 586).

22 Пантологија садржи пародије и на одређене особености и ставове француских симболиста, а парнасосимболизам основни је узор француских ђака Б. Поповића, Ј. Дучића и М Ракића. 
библиотеци Албатрос, поред Дневника о Чарнојевићу - 1921, М. Црњанског, као главни уредник, издаје Бурлеску господина Перуна бога грома - 1921, Р. Петровића, као и свој Громобран свемира - 1921); Винавер је био успешан преводилац, а његов превод Раблеове (1494-1553) Гаргантуе и Пантагруела (1532-1534) цењен је као један од најбоље изведених светских превода ове средњовековне дијаблерије (посебно су карактеристични експресивни изрази и псовке, вулгаризми и сложенице које карактеришу искривљени гротескни свет Гаргантуе).

Ближем одређењу стила збирке пародија С. Винавера претходи утврђивање природе песништва, атмосфере и типа комичног које се у делу остварује. Доминантан аспект текстова је хуморизам - озбиљне ставке $и$ критика песништва представљене су у комичном маниру. Ипак, комика има разноврсне начине изражавања, а пародија, као посебан вид комедије, поседује двоструке критеријуме на основу којих може да се спроведе кроз текст. Основни аспект пародирања јесте исмевање и поруга. Изругивање, сматрамо, може имати два облика изражавања: 1) прости; 2) сложени.

Прости тип подразумева изругивање ради лакрдијаштва; такво изругивање односи се на пародију или имитацију особина неког дела или личности, углавном је сценично артикулисано и не преноси се у писану форму, повезано је са свакодневним ситуацијама, карактерише га фарсична атмосфера и изводи се у бурлескним ${ }^{23}$ представама. Сложени тип поруге продуктивно је текстуалног карактера и односи се на ерудитни вид исмевања. Тип пародије која исмева или приказује особине и манир неког писца или епохе добија сатирични карактер, а сатира је сложени облик комедије - функција је критика друштва или појединца. Скуп Винаверових текстова представља скуп поетских текстова који обједињавају карактеристичну слику српског песништва романтизма и модерне - пастиш ${ }^{24}$ текстова. Представљање пародије текстуалним комичним изразом са скривеним значењем (другачије или супротно од исказаног) приближава Винавера и иронијском дискурсу (приметни су и аутоиронијски пасажи). Према Хачион, иронија је блиска пародији. Она каже: „Иако је по структури слична метафори (па самим тим и пародији) иронија је 'субстрактивна' у смислу [...] да оба нивоа значења морају структурно коегзистирати [...]" (Hutcheon, 2000: 34) Дистинкција коју има пародија у односу на бурлеску је она која се односи на персифлажу и фарсу. Персифлажа претпоставља исмевање и изругивање на фин начин, док се фарсичност редовно повезује са вулгарном и грубом комиком.

\section{2. Композиција и стил Пантологије}

Уколико пародију посматрамо посредством дефиниције „песма о песми“, онда, Пантологију (збирка пародија) можемо посматрати као метатекстуалну збирку или текст који настаје под утицајем другог текста - текст о тексту. Вр-

23 Бурлеска представља лакрдијашку шалу, односи се на шаљиво приказивање озбиљних ствари.

24 Пастиш подразумева подражавање манира неког сликара, композитора или, у овом случају, писца (у складу је са имитативни особинама пародије), али представља и превару, обману или издавање нечега за нешто што није (у складу је са антитетичним својством пародије и супротним значењем од исказаног). 
ста Винаверове комедије односи се, пре свега, на сатирични и критички аспект комедије. Унижавање стила присутно је у Пантологији, а познати су и његови вулгаризми у преводу Гаргантуе и Пантагруела, али док дело посебно наглашене гротескне визије света то и изискује, збирка пародија српског песништва другачије је конструисана. У Пантологији је заступљена и травестија르, која је најприметнија у пародирању жанрова. Збирка садржи пет одабраних предмета пародије: 1) пародија епохе; 2) пародија писца; 3) пародија жанра; 4) пародија манира; 5) пародија атмосфере.

Петоделна подела чиниће окосницу нашег истраживања, као и класификацију Винаверове пародије у Пантологијама. Винавер је био и књижевни теоретичар ${ }^{26}$, био је ангажован у литерарној борби са другим авангардним ауторима, захтевао је ново у српској књижевности - потрес који би пореметио успостављену равнотежу. Пантологија представља померање писца ка књижевном прогресу. Овом збирком нападнути су ауторитети, књижевни критичари, као и значајни писци. Природу Винаверовог дела чини дисхармонија, изврнути поглед на свет или, како Фрај (1912-1991) наводи, као особеност сатиричног изражавања, „визија света постављеног наглавце којим владају хумори и опсесије“ (Fraj, 1979: 256).

Винавер је сатиричар, а смех сатиричара представља коректив друштва. Смех је првенствени принцип Винаверовог књижевног рада. Како истиче Свирчев: „Отклон од сваког аподиктичног суда у најинтимнијој је вези са Винаверовим светоназором и његовим посезањем за смеховним и темељ је [...] његовог концепта културе“ (Свирчев, 2014: 180). На семантичком плану, писац Пантологије не наводи конкретне особености поезије каква би требало да буде, искључиво скреће пажњу на песништво, поиграва се формом, приказује неподударности. Пародија Пантологије често се приближава апсурду - Винаверови стихови су бесмислице ${ }^{27}$, али препознатљиве бесмислице које нам дозвољавају да уочимо предмет исмевања (писца, песму, епоху). Комика, садржана у овим песмама, вербалног је типа, кратка је и сажета, доминира принцип reductio ad absurdum. На језичком плану, честа је игра речима. У погледу стилског поступка, присутни су каламбур, алузија, парадокс, апсурд.

Доминантна особеност Винаверовог пародичног стила огледа се у игри речима, а међу значајнијим фигурама, употребљеним у Пантологији, издваја се каламбур: досетка или, дословно, игра речи - каламбур се тумачи као употре-

25 Травестија претпоставља раскорак у форми, жанрови за које је карактеристично узвишено певање или високи стил (елегија, ода, химна), унижавају се атмосфером и језичким облицима карактеристичним за нижи стил.

26 Написао је Манифест експресионистичке школе садржан у спису Громобран свемира.

27 Ј. Деретић (1934-2002) у Краткој историји српске књижевности (1986) наводи за Винаверово песништво: „Винавер је хтео да створи песме ослобођене од сваког конкретног значења, песме које ће самим својим звуком изразити најдубље трептаје бића. Веровао је да је свака конкретизација, свако именовање, смртна опасност за песму, да је бит песме у наговештају а најбољи начин да се наговештај оствари јесте музика [...]“ (Деретић, 1986: 10.6.2021.). Две основне особености Винаверове поезије су „музика“ и „комика“, музика је доминантна у раној симболистичкој збирци Мјећа, а комика доминира у збирци пародија Пантологија. 
ба речи са двоструким значењем. Присуство каламбура уочљиво је у наслову Пантологија новије српске пеленгирике. Одредница „Пантологија“ упућује на познату Антологију Б. Поповића коју и пародира. Пеленгирика је, опет, сложеница која садржи лирику. У питању су ставке које, пратећи природу каламбура, говоре о насловом истакнутој игри речи, што појачава стилски и пародични ефекат дела. Каламбур представља игру речи истог или сличног гласовног склопа (пантологија/антологија; лирика/пеленгирика), а различитог значења (антологија: скуп најбољег песништва; пантологија: изругивање антологијском оцењивању песништва). Унижавање које Винавер изводи навели смо у аналогији значења речи „пеленгирике“ као „пелѐнгаћа“ (уп. Сељачки Мирковић, 2015: 610-611), где је очигледна производња поспрдне комике на тему Поповићеве Антологије и песама које она садржи. Сличан поступак може се употребити и у вези са изразом „пелѐнгйр“ (мали стуб о који је пре батињања везан какав злочинац да га сви виде).

Игра речима приметна је и у стилској употреби псеудонима. Псеудоним представља лажно или измишљено име, а књижевни псеудоним је име које је као узусно прихватио неки писац. Пре Пантологије, у Мјећи 1911. године, Винавер је насловио сегмент под називом Песнички списи Трајка Ћирића (млађег) (в. Сељачки Мирковић, 2015: 609). Име Трајка Ћирића није употребљено само на овом месту. У часопису Пијемонт 1912. године објављена је „Анкета г. Трајка Ћирића“, замишљена као отворена полемика о начелима Б. Поповића, на основу којих настаје Антологија новије српске лирике (Сељачки Мирковић, 2015: 609). Пародична псеудонимска расправа није била претерано успешна, а на анкету се одазвао само песник С. Стефановић (1877-1944) (Сељачки Мирковић, 2015: 609). Поред псеудонимског паралелизма у имену Трајка Ћирића, којим је Винавер желео да уздрма аутоматизовану атмосферу званичне науке о књижевности, у овом имену садржана је друга фигура, значајна за Пантологију.

Винаверова Пантологија пародија је на Антологију новије српске лирике Б. Поповића, а тим својством уочава се заступљено стилско средство алузије. Алузија је стилска фигура исказа, она своје значење остварује на тај начин што једним исказом упућује на неки други догађај, другу особу или појаву. Алузија у имену Трајка Ћирића већ је наговештавала подсмешљиву усмереност према песницима. Псеудоним Трајко Ћирић може бити алузија на песника В. Илића, а додатак „млађи“, садржан у поднаслову збирке Мјећа, може упућивати и на В. Илића Млађег, ванредно пародираног у Пантологији - у контексту родољубиве поезије (в. Сељачки Мирковић, 2015: 610). Винавер је пародирао и старијег и млађег В. Илића. Пантологија, на тај начин, може се тумачити и као збиркаалузија јер је, почевши од наслова (односи се на Поповићеву Антологију), па посредством целокупне садржине дела, у питању скуп или пастиш алузија на писце, песнике, њихове текстове и појаве у песништву српског романтизма и модерне.

Алузија Винаверова наставља се у кратком предговору аутора у Пантологијu. Предговор је подељен на четири сажета дела означена римским бројеви- 
ма. У првом делу, карактеристичан је навод у коме пише да је састављач књиге „потписани“ (Винавер, 1966: 9). У другом формативном делу предговора пародира се структура, при чему је пеленгирика попут антологије подељена у историјске периоде, а периоди код Винавера насловљени су као: варваризам, питомизам, неоварваризам, неопитомизам (Винавер, 1966: 9). Томе је прикључена поука дела: „то јесте ново, питомо гледање на свет“ (Винавер, 1966: 9). Трећи део садржи уредникова мерила: спис мора бити написан; не сме бити преписан; и мора бити потписан (Винавер, 1966: 9). Уочљива је пародија и тривијализација троструке поделе коју Поповић даје у предговору Антологије: песма мора имати емоције; мора бити јасна; мора бити цела лепа (1994: 13). У истом одељку Винавер исмева Поповићеве ставове према којима „нема добрих песника, само добрих песама“ (1966: 9). Књижевни критичар сматра „добри песници тако се зову само по метонимији“ (Винавер, 1966: 9). У Пантологији се каже „[...] нема клавира, већ постоје само песме, и нема месеца, већ постоји само месечина. Отуда је и пеленгирика независна од пеленгира“ (Винавер, 1966: 9).

Приметно је присуство апсурда којим се врши тривијализовање Поповићевих премиса, али и оцена ставова књижевне критике уопште. У четвртом и завршном делу предговора наводи се „Уредник мисли да је Бергсон један пацер, иако је професор. Ово, додуше нема везе са Пантологијом, али је живот као и мачка“ (Винавер, 1966: 10; Винавер, 2012: 9). Наведено место, према Ранчић, представља алузију на Једну критичку анализу Б. Поповића (Rančić, 2012: 61). Логички удаљеним премисама аутор додатно успоставља апсурдну визију света. Бележимо и референцу на Бергсона (1859-1941) чији је рад имао значајни утицај на Винавера ${ }^{28}$. У Најновијој пантологији српске и југословенске пеленгирике из 1938. године Винавер додаје Предговор другом издању, који представља допуну претходног Предговора. Наиме, након готово двадесет година размака, аутор наводи да се ништа није променило у српској књижевности: „Место старога фељтона дошао је нови фељтон, место старе дидактике - нова дидактика, а место старе плиткости, нова плиткост“ (Винавер, 2012: 194).

Посредством класификације Винаверове пародије, сви сегменти, наслови, екстратекстуални додаци, биографски подаци и песме, сачињавају збрирку алузија, а алудирање је основна стилска формација Пантологије. Карактеристичне алузије на писца, превасходно, проналазе се у додатку збирци, које је аутор насловио „Лични подаци“ (в. Винавер 1966: 185). Овај део књиге претпоставља пародију кратких биографија писаца и књижевних критичара. Винавер наводи специфичне особине за сваког аутора. За Црњанског каже: „Дуго времена проповедао је да треба бити као дрво. Зато је метаморфозиран у букву у Итачкој

28 Винавер је као хумориста био упознат са радом А. Бергсона на плану комике и комичног. У цитираном делу употребљава се апострофа. Аутор дозива Бергсона и његова становишта о комедији зарад борбе против књижевне критике. Пародија претпоставља исмевање по принципу имитације или подражавања, а подражавање Бергсон види као аутоматизам поступака, што омогућава налет смешног. Француски филозоф, у студији О смеху (1900), истиче „[...] сада имам пред собом механику која делује аутоматски. То више није живот, то је аутоматизам настањен у животу и који подражава живот. То је комика.“ (Bergson, 2004: 33) 
шуми“ (Винавер, 1966: 187); за Пандуровића (1883-1960), користећи псеудонимску пародију, истиче: „Дошао је на престо поезије после абдикције Јована Дучића, под именом Симеон Први Pessimissmus“ (Винавер, 1966: 186); Под одредницом „Јован Дучић“ наводи: „Страстан колекционар, у своје време скупљао чак и стихове, по угледу на Алфреда де Мисеа и друге савремене писце“ (Винавер, 1966: 188); Карактеристичне су и црте А. Шантића (1868-1924): „Аутор чувене драме Остајте у Аустрији ${ }^{29}$. Његова слабост била је Мостар и стала га главе: погинуо је у пожару који је упаљен, као што је познато, из севдалинки, очима једне Туркиње“ (Винавер, 1966: 188). Наведени пасажи о водећим песницима српске модерне лирике и такво, према Ранчић, приказивање „изврнутом логиком која биографију ликова често гради узимајући наслове, теме и мотиве песника као догађаје њихових живота, садрже, поред критичких осврта на појединачно стваралаштво и један мали наратив, који говори о смени власти у Царству поезије“ (Rančić, 2012: 64). Царство поезије или једна недељива органска целина, како то Поповић истиче за модерну српску лирику (Поповић, 1994: 11), претпоставља и владавину над истим. У таквом пародичном кључу Винавер наводи Дучића као „краља песника“, који ће са престола абдицирати у корист Пандуровића (Винавер, 2012: 54). Преношење узора и сличних песничких особености (тематика, атмосфера, версификација) међу песницима српске модерне, пародично претпоставља песничку примогенитуру (наследно право превођења; наследство престола).

Биографске одреднице у Винаверовој збирци очевидан су пример пародичног, али и духовитог односа према значајним песницима српске модерне (прави се осврт и на авангардне песнике), али у њима је садржан и други тип пародирања - пародија манира. Када се погледају карактеристчне црте, наведене за сваког писца, примећујемо етеризам (однос са природом, песник постаје дрво) и суматраизам (далеке везе, алузија на Лирику Итаке) М. Црњанског; примећујемо, такође, пародични алузивни осврт на Пандуровићеву декаденцију и осврт на његово песимистично ${ }^{30}$ песништво - Винавер га назива „Симеоном Првим Песимистом“ (Винавер 2012: 56). Песника је представио и као настављача Дучића, познатог и под називом Краљ песника (Винавер, 2012: 56). То нам приближава стилски формиран назив Пандуровића по узору на престолонаследника који на престолу наслеђује Дучића; Дучић је приказан још оштрије, замера се његовом подражавалачком маниру, наводи се француски романтичарски песник Де Мисе (1810-1857), а Дучић се назива сакупљачем песама (Винавер, 1966: 188). На овај начин Винавер алудира на слабу оригиналност какву замера Дучићу; манир Шантића исмејан је у погледу пренаглашеног сентиментализма

29 Иронични осврт на родољубиву песму „Остајте овде“ (алузија на анексију Босне и проблем територијалне надлежности - контрастирање питања државности и националног осећања).

30 Песимизам С. Пандуровића Винавер је исмејао у песми „Метафизика“. Илустративан је мотив метафизике као пример пренаглашених великих тема - питања о животу, смрти и души завијена песимистичним песништвом. Винавер исмева слабу вољу за животом лирског субјекта: „Живот је тежак као малтер перпендикулара,/Гнусни еуфемизам бреветира ропац,/Психологију делира харангира шкопац,/Ми смо монструм сумње у психи окулара,/И демон блуда у полусвету преживара [...]“. (1966: 91) 
на плану родољубља и у погледу слика љубави и жене, какве је имао мостарски песник. Ово је, вероватно, најлирскији опис од наведених - алудира се на познату песму „Емина“ у коју се песник заљубљује само на основу погледа: „пожар који је упаљен из севдалинки, очима једне Туркиње“ (Винавер, 1966: 188).

По питању пародије манира, а у контексту алузивног поступка, интересантан је пример песме „Хоћу“. Испод ове песме, на месту аутора, стоји „Безимени“. Хамовић пародију „Хоћу“ усмерава на М. Бојића, са којим је Винавер полемисао $^{31}$, али битније место од тога је пародија манира какав је успоставила књижевна критика на челу са Скерлићем ${ }^{32}$. У песми се исмева прописани канон писања: „Ја хоћу, хоћу, снажна ми воља,/Ја хоћу, хоћу, воља ми снажна,/И није сетна, сузама влажна,/Моја је воља у гневу зоља [...]“ (Винавер, 1966: 20). Винавер упечатљиво исмева послушничку природу највреднијих ученика Скерлићевог утилитаризма, а комично пркосна синтагма „ја хоћу“ подсећа на латинску мотивациону изреку „ја хоћу, ја могу, ја морам“. Илустративна је градација, односно, антиклимакс ставова римског центуриона који од вољног момента хтења долази до стања принуђености да се нешто учини. Таква принуђеност наговештена је и у песми - потреба да се удовољи критици, али пародија је комплетна јер је градација у узлазном тону. У песми се полази од личних осећања: „хоћу, снажна ми воља“ (І строфа), а потом она узраста и кроз појаву природних непогода: „хоћу, нек пада киша“ (II строфа). Та воља јача и док јачају непогоде: „хоћу, нек дивља врева/Олуја бесни, бесно нек сева [...]“ (III строфа) (Винавер, 1966: 20). Одредница „Безимени“ испод песме „Хоћу“ упућује на то да управо алузивна оданост Скерлићевој критици не треба да упућује на једног песника него на више њих - мноштво, а не индивидуум. Пародира се песничка школа произашла од Скерлића.

Пародија епохе у збирци пародија заузима значајно место, али треба имати у виду да типологија пародије не претпоставља по правилу екстрактоване типове, него је комбинован већи типолошки број. Пародија епохе не реализује се у делу самостално, већ иде у пару с пародијом манира, атмосфере и сл. Пародију епохе можемо уочити почетној песми насловљеној „Бела зора“, а приписаној Б. Радичевићу. У овој песми, пародира се фолклористички стил српског романтичарског песништва чије темеље је успоставио Радичевић. Поред језичких средстава, које одликују архаизми (руди, моми, метно), синтагматских конструкција карактеристичних за фолклорно песништво (зора бела), учесталог деминутивног изражавања (момчић, поточић, травицу, ветрић), присутно је и

31 Винавер је, посредством Пантологије, пародирао Бојића у две песме, али како је и Бојић био песник оштрог пера, он је Винаверу узвраћао пародијом. На тај начин М. Бојић пародира аутора Пантологије посредством његовог псеудонима у песми „Трајко Ћирић“: „Кад је Трајко чуво стадо,/Премишљао је врло радо/О причама критичара [...] Наједанпут, нуто чуда!/Паде једна књига с дуда,/Као гњездо пуно тића,/„Историја“ од Скерлића [...]“ (Хамовић, 2015: 591) Реч је о секундарном извору, цитат није преузет из Пантологија.

32 Алузија на Скерлићеву критику дословно је спроведена фуснотом и астериском који стоји изнад поднаслова Из зборника како треба писати. У фусноти Винавер пародично истиче „Ученици и ученице проф. Скерлића издали су недавно овај Зборник. Из њега се може видети како треба певати, писати, плакати, облачити се, живети и умрети.“ (1966: 20) 
пародирање теме. Честе теме код Радичевића, развијане у фолклорном циклусу песама, биле су песме са еротским мотивима и о односу момка и девојке. Пародирањем теме уприсутњена је пародија атмосфере, на овом месту, у контексту српског фолклорног романтизма радичевићевског типа.

Пародија атмосфере присутна је великом броју песама у збирци. Интересантна је пародична песма „Евдоксија“ у којој Винавер преображава родољубиви књижевни стил М. Ракића који се заснива на тематици српског средњовековља. Песма пародира тему средњовековне Србије, а за предмет пародије Винавер смело узима славне Ракићеве песме „Јефимија“ и „Симонида“. Референцу на „Јефимију“ прави у другој строфи, а помињање манастира у првој и завршној строфи упућује на Ракићев циклус песмама о средњовековним принцезама, чистог морала и светог ареола - узвишени принцип. Попут осталих тема, Винавер травестира атмосферу Ракићеве поезије, те наводи Евдоксију као младу девојку која је сита манастира - она бежи да би јој се придружило шест другарица које су исто тако младе и жељне (в. Винавер, 2012: 16). Пародирање средњовековних тема није тако једнострано у Винаверовој песми. С обзиром на то да је Ракић успешно писао и љубавне песме са наглашеним сензуалним тоном, оваквим паралелизмом, у песми „Евдоксија“, конструисан је пастиш песникових тема.

Пародија жанра, исто тако, формативни је аспект Пантологија и може се поделити у две врсте: 1) пародија књижевног рода (поезија, проза и драма); 2) пародија књижевног жанра (елегија, ода, епопеја, романса). По питању рода, иако је уобичајен Винаверов поступак пародирање песничког израза, Пантоıогија садржи и пародије прозних текстова. Један такав прозни текст у контексту пародије жанра је „Епопеја Винка Пожуновића“, а потписан је М. Крлежа. Приметна референца на Крлежино стваралаштво је појава лика Кристофера Колумба. Референца португалског морепловца упућује на Крлежин (1893-1981) драмски спис Кристофер Колумбоз3 (1917).

Крлежина драма, на језичком плану, обележена је експресивним изразима и натуралистичким описима човека и анималне телесности, беса, мржње и насиља. Атмосфера је обележена црном и тмурном буром и бродоломом - алегорија људског морала. Чланови посаде описани су као дивље животиње и гомила сулудог меса која се свађа, урла, куне и ждере се до крви и костију - опис човека рођеног inter urinas et faecas ${ }^{34}$. Претерани огиси неморала и људског

33 Тема Крлежине драме у основи разматра човека као морално питање, изложеност манама, покварењаштву, прљавштини и злу. Колумбо је представљен као Адмирал који своју посаду води у обећану Нову Земљу. На почетку драме Адмирал је обележен идеолошким дискурсом, верује да ће Нова Земља донети ново достојанство људима из његове посаде (низак сталеж, бандити, гусари). До краја драме Адмирал увиђа да је погрешио и да они желе у Нову Земљу само како би се накрали блага да би се у Шпанију вратили моћнији него што су били. Драму карактерише мотив путовања које треба да обезбеди сазнање и нематеријалну корист ликовима, али пут је обележен гротескном представом човека који не заслужује откриће - пут представља изневерено очекивање.

34 Латинска сентенца, варијанта израза „у урину и измету човек се рађа“, позната и у верзији inter faecas et urinam nascimur (рођени смо у урину и измету). Израз се, најчеше, приписује потенцијалним ауторима Бернару од Клервоа и Св. Августину. Најранија референца у штампаном извору је из 1875. године у часопису за филозофију De Levensbode, Eén achtste deel (ГАасник живота, Осми део), у којем су аутори холандски филозофи Јоханес ван Влотен и Хендрик Јохан Бец (в. Van Vloten/Betz, 1875: 532). 
безумља код Крлеже упућује на стилску фигуру преувеличавања. Хипербола, према Бахтину (1895-1975), основни је формативни елемент гротеске (Bahtin, 1978: 320). Бахтин, у студији Стваралаштво Франсоа Раблеа и народна култура средюег века и ренесансе (1965), у поглављу о гротесци, истиче: „Преувеличавање, хиперболизам, прекомерност, претераност су, опште је мишљење, једно од најбитнијих обележја гротескног стила (Bahtin, 1978: 320). На истом месту, руски семиотичар, говори о увећавању делова тела као пример гротескности ${ }^{35}$, а које је присутно унутар пародије Крлежиног текста. Гротескну визију света карактеришу претеране представе, велика увећања, слике дивова (Гаргантуа и Пантагруел), ружноће (статуе Гаргојла) и контрастна представа лепог и ружног у једном (Квазимодо - половично формиран). Гротеска је, дословно, слика на пола, таква наглашена представа света предмет је пародије у Винаверовом тексту.

Наглашена хиперболизација изразито је заступљен елемент у комици С. Винавера, а корени тога проналазе се у карневализацији и народној комици средњег века. Интересантна је блискост Винавера и Бахтина у погледу Раблеовог романа Гаргантуа и Пантагруел, а оглед о средњовековној култури Средњовековни богохулници и безбожници српски аутор је написао 1955. године, десет година пре Бахтинове студије о Раблеу (в. Свирчев, 2014: 182).

Као пример пародије жанра, пре свега, епопеја, означава јуначки спев или песничко приказивање великих догађаја који се повезују са једним ликом или средиштем збивања (Илијада; Одисеја; Енеида). Епопеја је углавном састављена од народних песама и прича, али може бити и уметничка по начину настанка. Уметничка епопеја дели се на: 1) историјску (опева историјске догађаје); 2) романтичну (опева витешке пустоловине); 3) побожну (садржи делове Светог Писма); 4) комичну (машта и разум се сукобљавају, присутан је контраст). Винаверову пародичну епопеју прихватићемо као комични тип.

Можемо говорити о контрасту ${ }^{36}$ као дистинкцији пародираног текста и самог текста пародије. Винаверова пародија, у односу на прототекст, не говори ништа о бродолому и бури на мору, али су преузети натуралистички описи човека, гротескна визија, сецирани соматизми и хиперболични описи ${ }^{37}$ (в. Винавер, 1966: 131-133). Оно што Винаверову Епопеју чини пародијом у односу на Крлежин драмски спис јесте комична атмосфера и пародични манир на који су употребљени хиперболични описи. За разлику од моралног подтекста Крлежине

35 У тексту стоји: „Иста таква упадљива преувеличавања карактеристична су и за слике тела и телесног живота код Раблеа“ (Bahtin, 1978: 320).

36 Фигура коју карактерише противност, супротност и наглашена разлика између два члана успоредбе.

37 Сликовити су примери гротескних хиперболичних описа који подсећају на стил уочљив у Винаверовом преводу Гаргантуе и Пантагруела: у целим вилицама, гнојавим и набубрелим; лишајевима обрасли нос; Зевс је имао два вештачка зуба (пример је умањивања и унижавање божанског) (Винавер, 1966: 131); спарушене жене секле су тупим и прљавим маказама огавне црне нокте и боцкале се по отромбољеним дојкама. Уочљива карактеристика гротескних хиперболичних израза је да они увек зависе од алегоријских и метафоричких слика и то метафоре ружног. Могу се навести и друге метафоре ружног, поређења и епитети изузети од хиперболе: баба са сврабом, матроне гноја; зуб: крњ, црн, труо као лешина. 
драме, Винавер сав трулеж човеков пребацује на раван његове телесности. На тај начин, Епопеја почиње описима трулежа и смрада који долази из уста и зуба:

Доктор пажљиво враћаше рупу у зубу. Зуб је био труо и гадно је мирисао: „Сви су такви“, мишљаше Винко. „Ко има добре зубе? Свима смрде уста. Ето и генерал фон Лудендорф тужи се на зубобољу у својим дневним заповестима. Како ли њему смрде уста! Овај смрдљиви рат можда се само и води због зубобоље и шуге. (Винавер, 1966: 130)

Пример завршетка Винаверовог текста садржи апросдокетон ${ }^{38}$ „„И већ многим људима то поче кварити срећу и радост. Најзад, Линко Тожуновић, кога је тај мирис доводи до беснила....... (Овде почиње слична прича, али у инверзији. Види почетак)“. (Винавер, 1966: 133) Овакав крај може представљати пародију Крлежиног поступка изневереног циља у путовању јунака и протагониста дела. Инверзија коју Винавер помиње пародични је приказ, свет окренут наглавце, а повратак на почетак представља логичку грешку circulus vitiosus. Инверзија значи премештање или обртање реда речи или делова реченице. На синтаксичком плану, инверзија претпоставља ред обрнут од оног који је граматички очекиван. Винаверова инверзија у Enoneји је инверзија текста и она је више семантичко питање. Инверзија коју писац спроводи на овом месту није граматичка него значењска (пародија натуралистичких описа доприноси другачијем значењу него што је то случај код таквих описа у прототексту).

Жанрови које Винавер бира као предмет пародије, а на плану поезије, по правилу, односе се на песништво високог стила наглашеног и усхићеног певања. Пример пародирања таквог жанра је елегија. У питању је уметничка песма у којој песник износи своја осећања (туга, бол, жал за пролазношћу). Значајни представници у српском песништву били су Ђ. Јакшић, J. Ј. Змај, В. Илић (пародирани су у Пантологији). „Елегија“ у збирци приписана је мање истакнутом песнику В. Станимировићу 39 (1881-1956). Поред учесталих родољубивих песама, Станимировић је писао љубавне песме и сонете. „Елегија“ у Пантологији пародира манир писања који је посебно уочљив на језичком плану. Пародирање стила или манира писца посебно запажамо у архаичним партикулама „ду“ (удаду - I и IV строфа), као и у скраћеним архаизмима (Ђид(')о, рид(')о) (Винавер, 1966: 22). Сличан вид архаизације у стихотворству може се уочити у појединим Станимировићевим песмама.

Поред језичких особина, карактеристика стихова је и елегична атмосфера, наглашена осећајност, присуство бола, тема младости, циклуса пролазности и обнављања. Винаверова пародија преображава романтичарску сентиментал-

38 Апросдокетон представља фигуру изневереног очекивања. Она садржи ненадан и неочекиван израз наместо очекиваног. Аналогно природи Винаверове пародије, апросдокетон се у причи не реализује синтасички, на плану реченице, већ семантички, на плану текста - промењено значења текста.

39 Био је правник, књижевник и преводилац и најпознатији је по стиховима уклесаним на споменик преминулих војника и официра Дринске дивизије у селу Агиос Матеосу, на Крфу (Крфски епитаф). 
ност и архаизме, које имитира, преноси у шаљиви народни облик, притом, задржавајући тему грађанства: „У једном граду/Девојку младу/Хоће д‘ удаду./ Кад сам то видо/Ја не бих ђидо,/Дуго сам ридо“ (Винавер, 1966: 22). Сличан вид пародирања високих песничких жанрова можемо пронаћи и на плану оде. Винавер оде пародира, по правилу, у духу раних Змајевих високопарних стихова. Пример пародије оде је песма „У име речног“, која је приписана С. Стефановићу. На плану пародирања оде Сељачки Мирковић говори: „[...] несклад између предмета певања и поетског израза производи комичан ефекат, од озбиљног поетског облика ствара хуморно дело, још више наглашавајући високопарном интонацијом тривијалност и ништавност теме“ (2015: 623).

Пародија жанра или песнички поступак насловљавања песме наговештајем жанра, а писањем другачије садржине, карактеристичан је за песнике српске авангарде. Најзначајнији пример песника који се бавио трансформацијом жанрова вероватно је М. Црњански. Винавер, као његов близак сарадник и пријатељ, заједно је учествовао са Црњанским у књижевним и уређивачким пројектима (часописи, књиге - библиотека Албатрос). Заправо, Винавер је у појединим есејима и предавањима бранио песничка становишта Црњанског. Ипак, како је његова пародија свеобухватна и непропустљива - ни по бабу ни по стричевима, Винавер ће пародирати и неке од својих сабораца и истомишљеника попут суматраистичког песника. Интересантан пример пародије Црњанског проналазимо у песми „Разочарење“. Треба имати у виду да је Црњански, на самом почетку стваралаштва, млади разочарани песник авангарде са збирком Лирика Итаке (1919), која представља скуп ироничних осврта на српске романтичне стихове, историјске теме и доминантну атмосферу косовског мита међу српским, не само песницима него и уметницима ${ }^{40}$. Алузиван је сам наслов песме „Разочарење“, које упућује на превирање у осећањима српског песника. Винавер пародира контрастне иделошке ставове:

Ја не верујем више у Копаоник и у Гецу Кона

И у Манасију мермерних кула.

У мени звоне потмула

звона.

Отаџбина је опора и трула

Мушмула. (1966: 39)

Одмах затим, као песник, војник и родољуб, почиње да пише велике поеме (Стражилово - 1921; Сербиа - 1925; Ламент над Београдом - 1956), које

40 Позната је песма М. Црњанског „Гротеска“ у којој се, између осталог, алудира на претерану монументалност међу уметницима и критику Видовданског храма И. Мештровића (1883-1962), песма се и налази у циклусу насловљеном Видовданске песме. Гротеска је изузетно алузивна и испуњена снажним симболима у циљу стилског и религиозног контрастирања: „Зидајте храм/бео као манастир./Нек шеће у њему Месец сам/И плаче ноћ и мир./А на храм дижите црну/сфингу народа мог./Нек се све звезде што језде осврну/за смех чудовишта тог.“ (Црњански, 1994: 18) 
су окарактерисане узвишеним националним осећањем. Осим идеолошког момента, пародира се и преводилачки рад Црњанског, а у погледу антологијског сакупљања песама. Црњански је превео и сакупио Антологију кинеске лирике, која садржи најзаначјније песме из кинеског песништва и таоистичког стихотворства, почевши од Лао Цеа (601. п.н.е. - 531. п.н.е.) и Конфучија (551. п.н.е. - 479. п.н.е.), па до Ли Таи Поа (701-762), Ту Фуа (712-770), Ванг Веиа (701-761) (в. Црњански, 1993: 379-399). Суматраистички расположен Црњански је био пасионирани заљубљеник у кинеску лирику, а Винавер је, на том месту, пронашао простора за пародију. Пантологија садржи три готово идентичне песме о „расцветалој трешњи“ насловљене: „Сутонско уздарје“; „Сумраков поклон“; „Дар првога мрака“. Наслови представљају само перифрастичне варијанте које наговештавају мотив расцветале трешње на месечини. Осим наслова, прве две песме су идентичног садржаја, пародира се мистика источњачког сажетог стила:

Ти гледаш расцветалу трешњу

И месечев рог,

Који обасјава

Расцветалу трешњу.

И ти мислиш о расцветалој трешњи

И о месечевом рогу,

Који обасјава Расцветалу трешњу... (Винавер, 1966: 144-145)

Мали, дистинктивни и шаљиви детаљ који ће Винавер начинити је податак који стоји испод две песме: у питању је информација о преводу са енглеског, у првој песми, као и са француског језика, у другој песми (в. Винавер, 1966: 144145). Трећа варијанта наговештена је напоменом у пост скриптуму, у којој стоји да је аутор превод сличне песме са старословенског пронашао у једном фрушкогорском манастиру (в. Винавер, 1966: 145). У овој варијанти, мотив трешње замењен је ананасом, све до последњег примера где стоји кајсија. Винавер, у напомени, такав детаљ, објашњава речима „[...] то долази отуд што у то време Банаћани нису познавали трешње, а пошто су, као и увек, били врло отмени, то су непознату реч трешња заменили познатијом ананас. Што се тиче речи кајсија, она је ту ушла сигурно непажњом каквог мање отменог преписивача“ (Винавер, 1966: 146). Аутор у фусноти наводи могућност постојања четврте варијанте, на Исланду, само што тамо уместо трешње стоји медвед (Винавер, 1966: 146). Предмети пародирања у овим, донекле, лакрдијашким пошалицама, вишеструки су. Поред антологијског подухвата Црњанског, уочавамо и културлошки коментар и пародију малограђанства где Мачванин Винавер исмева тобожњу отменост Банаћана ${ }^{41}$, али и преписивачке манастирске школе - паралелизам са песницима подражаваоцима из модерне. Он је, на овом месту, исмејао и велики

41 Мотив кајсије, за коју Банаћани нису знали у IV веку пре Христа (пародија древних Банаћана - паралелно са древном Кином, они постоје у IV веку п.н.е.), замењен је мотивом ананаса који је, заправо, егзотичније воће од трешње. 
број сличних варијанти песама из кинеске лирике, које је Црњански уврстио у антологију.

Завршни поступак пародирања које бисмо навели на примеру Винаверове Пантологије јесте принцип аутопародије и аутоироније. Винавер, дакле, у збирци пародија не уврштава само познате представнике романтизма и модерне или илустративне примере мање познатих песника сличних стилских формација; уз њих, он уврштава и истомишљенике, али и сопствено песништво. Као пример аутопародије наводимо песму „Рођење малога крокодила“42.

\section{3. Закључак}

У раду смо, на плану књижевне стилистике, анализирали пародични поступак С. Винавера у збиркама Пантологија. Рад је подељен на два потпоглавља. У првом потпоглављу разврстали смо типове жанрова $и$ ауторске аспектуализације света (пародија, апсурд, гротекса), наратолошког роint of view, какав је развијен у Пантологији. Амбивалентни принцип пародије, као жанра, аспекта света и стила нужни је услов контекстулизације и методолошког књижевностилистичког приступа књижевном делу (уоквирен је став писца као предмет дела). Метод истраживања у раду је дедукција, закључивање од општег ка посебном. Тумаче се принцип пародије и њене трансформативне могућности у уметничком тексту. Комедију С. Винавера одредили смо као сатиру, критику књижевно-критичке реалности, али и продуктивни хумористички вид превредновања традиције. Заступљена је вербална лака комика наспрам грубој вулгаризованој фарси.

Друго потпоглавље рада говори о структурној грађи и најфреквентнијим стилским поступцима унутар пародије дела. Структурно смо збирку означили петоделном поделом пародија по врсти (пародија епохе; пародија писца; пародија жанра; пародија манира; пародија атмосфере). На основу ових типова, разврстали смо њихове особености (радичевићевска фолклорна атмосфера; пандуровићевски песимизам; тривијализација жанрова) и начине на који се они реализују у делу. У погледу имитативних или миметичких својстава текста о тексту или песме о песми, најзаступљенији поступци су алузија, на плану стилистичког аспекта дела, као и травестија, на плану жанровског комедиографског одређења.

Карактеристичне фигуре које чине стилску формацију Пантологије односе се на игру речи, каламбур или досетку (наслов и екстратекстуални слој књижевног дела); алузију као текст о писцима, песницима; критичарима (биографски додаци); псеудонимска и антономазична преименовања, апсурд (поетски текстови збирке). Пародију смо означили као фигуру на граници; она поседује стилогени потенцијал, али не стилематичну форму, карактеристична је као поглед на свет - видимо је као „фигуру погледа“ (став писца). Пародија је визуелизација

42 „Родио се мали Крок-/Одил у непарни Дан,/Пио је кокосов сок/И ишо неочешљан./Живео је малени Крок-/ Одил, не као свак:/И пре но што дошао је рок/Свукао је свој влак./А када се због зиме/Загњурио у језеро Нил,/Надели су му име:/Церебрални Крокодил!“ (Винавер, 1966: 63). 
пародираног прототекста у једној новој, промењеној и преокренутој форми са другачијим значењем.

Винавер у Пантологији пародира значајне представнике српског песништва романтизма и модерне. Пародирање њихових песама и других текстова представља критички став и превредновање традиције - потребу за новим у књижевности. Ипак, тежина Винаверове пародије, не заснива се само на критици његових неистомишљеника и личној борби против Скерлића и Поповића, већ збирка садржи и пародије на авангардне песнике, ближе његовој поетици, на његове блиске сараднике и пријатеље (Црњанског, Петровића), као и на његово сопствено песништво.

\section{Литература}

Брајовић, Т. (2015). Станислав Винавер као поетички волшебник српског модернизма. У П. Петровић (ур.), Поезија и модернистичка мисао Станислава Винавера: зборник радова (стр. 112-127). Београд: Институт за књижевност и уметност.

[Brajović, T. (2015). Stanislav Vinaver kao poetički volšebnik srpskog modernizma. U P. Petrović (ur.), Poezija i modernistička misao Stanislava Vinavera: zbornik radova (str. 112-127). Beograd: Institut za književnost i umetnost]

Винавер, С. (1963). Језичке могућности. У Р. Константиновић (ур.), Надграматика: избор из есеја (стр. 143-186). Београд: Просвета.

[Vinaver, S. (1963). Jezičke mogućnosti. U R. Konstantinović (ur.), Nadgramatika: izbor iz eseja (str. 143-186). Beograd: Prosveta]

Вукићевић, Д. (2018). Пародија у српској реалистичкој прози. У Д. Иванић и Д. Вукићевић (ур.), Поетика српског реализма: зборник радова. Београд: Филолошки факултет.

[Vukićević, D. (2018). Parodija u srpskoj realističkoj prozi. U D. Ivanić i D. Vukićević (ur.), Poetika srpskog realizma: zbornik radova. Beograd: Filološki fakultet]

Деретић, J. (1986). Кратка историја српске књижевности. Пројекат Растко: Библиотека српске културе на интернету. https:/www.rastko.rs/knjizevnost/ jderetic_knjiz/

[Deretić, J. (1986). Kratka istorija srpske književnosti. Projekat Rastko: Biblioteka srpske kulture na internetu. https://www.rastko.rs/knjizevnost/jderetic_knjiz/]

Кебара, Ђ. (2020). Наративне претпоставке и метатекстуална пародија у Роману без романа Ј. С. Поповића. Наслеђе, 46, 237-250.

[Kebara, Đ. (2020). Narativne pretpostavke i metatekstualna parodija u Romanu bez romana J. S. Popovića. Nasleđe, 46, 237-250]

Ковачевић, М. (2015). Стил и језик српских писаца. Београд: Завод за уџбенике.

[Kovačević, M. (2015). Stil i jezik srpskih pisaca. Beograd: Zavod za udžbenike]

Матицки, М. (1990). Винаверов одурок од десетерца. У Г. Тешић (ур.), Кюижевно дело Станислава Винавера: теорија, есеј, критика, поезија, проза, језик и стил, преводилаштво/компаративне теме, разно: зборник радова (стр. 209-214). Београд: Институт за књижевност и уметност. 
[Maticki, M. (1990). Vinaverov odurok od deseterca. U G. Tešić (ur.). Književno delo Stanislava Vinavera: teorija, esej, kritika, poezija, proza, jezik i stil, prevodilaštvo/ komparativne teme, razno: zbornik radova (str. 209-214). Beograd: Institut za književnost $\mathrm{i}$ umetnost]

Перишић, И. (2006). Једно виђење односа пастиша и пародије. Наслеђе, 3(4), 63-76. [Perišić, I. (2006). Jedno viđenje odnosa pastiša i parodije. Nasleđe, 3(4), 63-76]

Свирчев, Ж. (2014). Концепт смеха Станислава Винавера. У М. Анђелковић (ур.), Савремена проучаваюа језика и књижевности: зборник радова са V научног скупа младих филолога Србије (стр. 179-189). Крагујевац: Филолошко-уметнички факултет.

[Svirčev, Ž. (2014). Koncept smeha Stanislava Vinavera. U M. Anđelković (ur.), Savremena proučavanja jezika i književnosti: zbornik radova sa V naučnog skupa mladih filologa Srbije (str. 179-189). Kragujevac: Filološko-umetnički fakultet]

Сељачки Мирковић, М. (2015). Пародија као књижевнокритички став Станислава Винавера. У Ј. Триван и Д. Којчић (ур.), Заноси и пркоси Станислава Винавера (стр. 606-647). Београд: Службени гласник.

[Seljački Mirković, M. (2015). Parodija kao književnokritički stav Stanislava Vinavera. U J. Trivan i D. Kojčić (ur.), Zanosi i prkosi Stanislava Vinavera (str. 605-647). Beograd: Službeni glasnik]

Станојевић, Н., Николић, С. (2021). Јован Дучић (1871-1943). Електронски каталог изложбе број 305. Нови Сад: Библиотека Матице српске.

[Stanojević N., Nikolić, S. (2021). Jovan Dučić (1871-1943). Elektronski katalog izložbe broj 305. Novi Sad: Biblioteka Matice srpske]

Тошовић, Б. (2002). Функционални стилови. Београд: Београдска књига.

[Tošović, B. (2002). Funkcionalni stilovi. Beograd: Beogradska knjiga]

Хамовић, Д. (2015). Пантологијски Винавер. У Ј. Триван и Д. Којчић (ур.), Заноси и пркоси Станислава Винавера (стр. 585-605). Београд: Службени гласник.

[Hamović, D. (2015). Pantologijski Vinaver. U J. Trivan i D. Kojčić (ur.), Zanosi i prkosi Stanislava Vinavera (str. 585-605). Beograd: Službeni glasnik]

Христић, J. (1966). Напомене. У С. Винавер, Пантологија српске и југословенске пеленгирике (стр. 197-200). Београд: Нолит.

[Hristić, J. (1966). Napomene. U S. Vinaver, Pantologija srpske i jugoslovenske pelengirike (str. 197-200). Beograd: Nolit]

Bahtin, M. (1978). Stvaralaštvo Fransoa Rablea i kultura srednjeg veka i renesanse. Beograd: Nolit.

Bandić, M. I. (1992). Parodija. U D. Živković (ur.), Rečnik književnih termina (str. 570571). Beograd: Nolit.

Bergson, A (2004). O smehu. Novi Sad: VEGA media.

Fraj, N. (1979). Anatomija kritike. Zagreb: Naprijed.

Hutcheon, L. (2000). A Theory of Parody: The Teachings of Twentieth-Century Art Forms. Urbana: University of Illinois Press.

Lešić, Z. (2010). Teorija književnosti. Beograd: Službeni glasnik. 
Perišić, I. (2012). Uvod u teorije smeha: kratak pregled teorije smeha od Platona do Propa.

Beograd: Službeni glasnik.

Prop, V. (1984). Problemi komike i smeha. Novi Sad: Književna zajednica.

Rančić, D. (2012). Anto-logika u ogledalu 'Dvojnika iz negativne dimenzije': 'Pantologije'

Stanislava Vinavera kao preispitivanje modela 'Antologije novije srpske lirike' Bogdana Popovića. Treći program, 44(153), 50-76.

Van Vloten, J., Beetz, H. J. (1875). De Levensbode. Eén achtste deel. Haarlem: I. De Haan.

\section{Извори}

Винавер, С. (1920). Пантологија новије српске пеленгирике. Београд: Напредак.

[Vinaver, S. (1920). Pantologija novije srpske pelengirike. Beograd: Napredak]

Винавер, С. (1922). Нова пантологија пеленгирике. Београд: Штампарија Мироточиви. [Vinaver, S. (1922). Nova pantologija pelengirike. Beograd: Štamparija Mirotočivi]

Винавер, С. (1938). Најновија пантологија српске и југословенске пеленгирике. Београд: Француско-српска књижара А. М. Поповића.

[Vinaver, S. (1938). Najnovija pantologija srpske i jugoslovenske pelengirike. Beograd:

Francusko-srpska knjižara A. M. Popovića]

Винавер, С. (1966). Пантологија српске и југословенске пеленгирике. Београд: Нолит. [Vinaver, S. (1966). Pantologija srpske i jugoslovenske pelengirike. Beograd: Nolit] Винавер, С. (2012). Пантологије; Алајбегова слама. Београд: Службени гласник. [Vinaver, S. (2012). Pantologije; Alajbegova slama. Beograd: Službeni glasnik] Поповић, Б. (1994). Антологија новије српске лирике. Београд: Српска књижевна задруга.

[Popović, B. (1994). Antologija novije srpske lirike. Beograd: Srpska književna zadruga] Црњански, М. (1993). Лирика. Београд: Задужбина Милоша Црњанског.

[Crnjanski, M. (1993). Lirika. Beograd: Zadužbina Miloša Crnjanskog]

Црњански, М. (1994). Лирика Итаке. Београд: Култура.

[Crnjanski, M. (1994). Lirika Itake. Beograd: Kultura] 


\section{Đorđe N. Kebara}

\section{Summary}

\section{STYLE AND PARODY IN STANISLAV VINAVER'S POETIC COLLECTION PANTOLOGIJA}

The subject of this paper is the literary-stylistic analysis of S. Vinaver's Pantologija, a poetic collection of parody. The deductive method is used to define the characteristics of the collection and its stylistic featues. The aim of the paper is to place this poetic collection on the literary-historical level in the context of parody writing in Serbian literature. Another aim of the paper is to provide an analysis of the stylistics of the author's text or metatext, and the author's use of rhetorical figures - parody, irony, allusion, etc. Vinaver's writing, which we look at from a viewpoint of parody, will be interpreted in the context of the writer's point of view or as contextualization of the author's world. Vinaver's parody is a critique of fashion in creation; it is a humorous vision of a twisted world. We will present Vinaver's parody through a five-part division, which consists of the parody of an epoch, parody of a writer, parody of a genre, parody of manners and parody of the atmosphere. The paper provides a schematically classified typology of S. Vinaver's laughter and comedy in his humorous poetry collection Pantologija.

\section{Key words:}

parody, style, anthology, pelengirika, collection of parodies, aspect of the writer 